\title{
8. The Right to Reparation for Victims of Armed Conflict
}

Carla Ferstman

\section{Introduction}

Both international and internal armed conflicts continue to have an acute impact on civilians and entire communities. Millions of civilians have been subjected to extreme forms of violence during and while fleeing conflicts, including mass deaths, torture, rape, sexual slavery, mutilations and other cruel and debilitating physical and psychological treatment, abductions, deportations and all sorts of destruction and looting to homes and communities. In addition to the impacts of these forms of targeted violence, the consequences of conflict for civilians include poverty, trauma, disease, family dislocation and displacement. Increasingly, women and children are targeted; they also face the brunt of the consequences of conflict. Added to this, the multiple destabilisations associated with conflict have a tendency to permeate post-conflict societies; weak law enforcement and infrastructure and lingering tensions continue to put civilians, particularly the most vulnerable ones, at risk of further violence long after the formal end of a conflict.

While these multiple and cross-cutting harms are increasingly being acknowledged, they are rarely addressed specifically. The fate of victims is often an afterthought in peace negotiations and justice processes and victims rarely receive reparations; reparations often having been subsumed by more negotiable or contingent notions of 'reconciliation', 'charity' or 'humanitarianism.'

'Reparation' is a concept with contested understandings depending on the discourse or discipline being used, which may include law, politics, international relations, religion, psychology, sociology, penology or any combination of them. It signifies the concepts of 
repair, 'making good', restoration, rehabilitation, vindication. In law, 'reparations' are understood as what is owed by a wrongdoer in response to a breach of an obligation.

Reparations feature in the law of armed conflict; however, the norms and procedures relating to the same are opaque, porous and largely insufficient. The legal lacunae relate to victims' limited standing to pursue claims, for what types of harms, against whom, in which forums and with which result, all of which are extenuated when claims are pursued extraterritorially. There are equally questions about the extent of States' and others' responsibility to afford reparations when wrongful conduct can be attributed to a number of actors.

The challenges for victims to achieve reparations are multiple and include a variety of practical access hurdles linked to poverty, marginalisation, discrimination and victims' typical lack of voice and political agency to compel those in positions of power to meet their rights and legitimate demands and needs. Who is understood to be deserving of reparations, particularly when a whole society may have suffered in different ways, can also introduce often sensitive and potentially divisive choices which can turn the process of reparations into a political project. If not handled with care, reparations may engender further distrust and resentment within communities, or foster stigmatisation. There is also a tendency for decision-makers to simplify victims and victimhood; to ignore the various ways in which victims suffer and the gendered nature of that suffering. To acknowledge differences in victims' perspectives, wants and needs can be too complicated for the post-conflict political environment and somehow too stark: decision-makers may have a general sense of empathy for the notion of victims but they rarely want to get too close, even if this results in the voices of the most marginalised being obscured.

In this chapter, I explore some of the main challenges for victims of armed conflict to obtain reparations, citing a variety of case examples. There have been some advances in victims' 
access to reparations largely as a result of the influences of human rights law on the law of armed conflict and a growing global movement to address the lacunae. However, progress has been piecemeal.

\section{The Right to Reparation: An Overview}

The notion of a 'right' to reparation has progressively become accepted as a matter of law. It entails victims' right to access domestic remedies in response to a violation (the procedural component) and the right to receive adequate and effective forms of reparation, which aim at 'eliminating, as far as possible, the consequences of the illegal act and restoring the situation that would have existed if the act had not been committed,' ${ }^{1}$ and may entail any combination of restitution, compensation, rehabilitation, satisfaction and guarantees of non-repetition (the substantive component). ${ }^{2}$

Victims' access to remedies is a hallmark of human rights protection - any person whose rights have been violated has the right to equal and effective access to justice before a court or like body before which a remedy can be sought. ${ }^{3}$ It is active and participatory and acknowledges and in fact fosters the agency of the individual or group to decide if, when, how and in which forum to assert rights. The UN Basic Principles and Guidelines on the Right to a Remedy and Reparation for Victims of Gross Violations of International Human Rights Law and Serious Violations of International Humanitarian Law make clear that access must be fair and non-discriminatory, and procedures must be accessible and suitable to take account of victims' particular needs. In practice, discrimination and marginalisation can inhibit access to justice or associated reparations processes; often, key documents are not

\footnotetext{
${ }^{1}$ Case Concerning the Factory at Chorzów (Ger v Pol) (1928) PCIJ Sr A No 17, para 47.

${ }^{2}$ Basic Principles and Guidelines on the Right to a Remedy and Reparation for Victims of Gross Violations of International Human Rights Law and Serious Violations of International Humanitarian Law (16 December 2005) UN Doc A/RES/60/147 (adopted without vote).

${ }^{3}$ MC Bassiouni, 'International Recognition of Victims’ Rights' (2006) 6 Human Rights Law Review 203.
} 
translated to local languages; information dissemination does not reach remote areas or reach those who cannot read; structures to ensure safety, privacy and dignity are not in place which can discourage many women and others who experience stigma from coming forward. ${ }^{4}$ The Basic Principles and Guidelines underscore that measures should be taken to 'minimize the inconvenience to victims and their representatives, protect against unlawful interference with their privacy as appropriate and ensure their safety from intimidation and retaliation, as well as that of their families and witnesses, before, during and after judicial, administrative, or other proceedings that affect the interests of victims. ${ }^{5}$ In a post-conflict context, the regular justice institutions may not be functioning or will be under extreme strain. Even in the best of circumstances they would be ill-equipped to deal with a flood of conflict victims with multiple harms. Practically, this has meant that in such circumstances specialist judicial or administrative structures are needed to give effect to victims' rights to lodge claims for reparations. The Basic Principles and Guidelines refer to such possibilities, indicating that '[i]n addition to individual access to justice, States should endeavour to develop procedures to allow groups of victims to present claims for reparation and to receive reparation, as appropriate. ${ }^{6}$ Remedies must be available to all persons within the State's jurisdiction, which has been understood to include non-citizens and instances when a State exercises effective control over an area outside its national territory. ${ }^{7}$

The standard of reparations first articulated by the Permanent Court of International Justice and which has thereafter framed the quantum and quality of inter-State claims is 'full,' as needing to wipe out all the consequences of the illegal act and reestablish the status quo

\footnotetext{
${ }^{4}$ C O'Rourke, F Ni Aolain and A Swaine, 'Transforming Reparations for Conflict-Related Sexual Violence: Principles and Practice' (2015) 28 Harvard Human Rights Journal 97, 137-139.

${ }^{5}$ Basic Principles and Guidelines (n 2) art 12(b).

6 ibid, art 13.

${ }^{7}$ Ilaşcu v Moldova and Russia (App no 48787/99) ECHR 8 July 2004; Al-Saadoon v United Kingdom (App no 61498/08) ECHR 2 March 2010.
} 
ante. ${ }^{8}$ It is described in the International Law Commission's Articles on the Responsibility of States (ARS) which covers all internationally wrongful acts, in these same terms. ${ }^{9}$

However, in practice, reparation rarely meets the standard of 'full'. This is partly because of the impossibility to undo or repair the harm caused by most heinous acts especially when perpetrated during conflict such as killings, rapes, torture and forced displacement. But it is also because of the enormity of the victimisation and the limited resources available to put to reparations at the end of a conflict, and only varying degrees of political will. A question arises as to how this exceptionalism impacts on the overall clarity of the rule. It has been argued that the disconnect demonstrates the tenuousness or even absence of a right to reparation, ${ }^{10}$ or the narrower point that it reveals the absence of a right to 'full' reparation. ${ }^{11}$ Tomuschat, for example, has argued that '[w]henever chaos and anarchy set in, the magnitude of the sums required for effective reparation makes it imperative not only on economic, but also on legal grounds, to call into question the seemingly invincible proposition that reparation must wipe out all of the negative consequences of an injurious act. ${ }^{12}$ However, it can and has been argued that the exigencies of particular situations do not lower the overall standards; the overarching rules remain even if for practical reasons, the results are abridged. ${ }^{13}$ It may be difficult for a wrongdoer to have all the necessary means for

\footnotetext{
${ }^{8}$ Chorzów Factory Case (n 1) para 29; Legality of the Threat or Use of Nuclear Weapons (Advisory Opinion) [1996] ICJ Rep 226, para 152.

${ }^{9}$ ILC, 'Report of the International Law Commission on the Work of its 53rd Session' (23 April-1 June and 2 July-10 August 2001) UN Doc A/CN.4/SER.A/2001/Add.1 (ARS), arts 31, 34 and commentaries thereto. See, Basic Principles and Guidelines (n 2) art 18, which describes 'full and effective' reparation for gross human rights and serious IHL violations.

${ }^{10}$ C Tomuschat, 'Reparation for Victims of Grave Human Rights Violations' (2002) 10 Tulane Journal of International and Comparative Law 157, 177-180.

${ }^{11}$ Jurisdictional Immunities of the State (Germany v Italy: Greece Intervening) (Merits) [2012] ICJ Rep 143, para 94.

${ }^{12} \mathrm{C}$ Tomuschat, 'Individual Reparation Claims in Instances of Grave Human Rights Violations: The Position under General International Law' in A Randelzhofer and C Tomuschat (eds), State Responsibility and the Individual - Reparation in Instances of Grave Violations of Human Rights (The Hague, Kluwer, 1999) 11. 12 Jurisdictional Immunities of the State (n 11) para 94.

${ }^{13}$ E Schwager and R Bank, Is There a Substantive Right to Compensation for Individual Victims of Armed Conflicts against a State under International Law?' (2006) 49 German Year Book of International Law $367,393$.
} 
making the required reparation. However, that inadequacy cannot exempt a wrongdoer from the legal consequences resulting from its responsibility under international law. As Judge Yusuf recognises in his dissenting opinion in Germany $v$ Italy, 'Such arrangements appear to have been resorted to for policy or practical reasons aimed at avoiding the prospect of innumerable private suits, or a delay in the conclusion of peace treaties and the resumption of normal relations between formerly belligerent States' ${ }^{14}$ they do not imply an absence of individual rights. ${ }^{15}$ The Basic Principles and Guidelines also take this approach, by recognising the importance for States to 'endeavour to develop procedures to allow groups of victims to present claims for reparation and to receive reparation,' 'in addition to individual access to justice'. ${ }^{16}$ The ILC has recognised the challenges posed by mass victimisation in the ARS. While an earlier version of the ARS exempted debtors from the need to afford full reparation when to do so would 'result in depriving the population of a State of its own means of subsistence', ${ }^{17}$ the final text of the ARS omits this provision and instead introduces elements of equity and reasonableness. This is most evident with the reference to restitution, which is only required if it 'does not involve a burden out of all proportion to the benefit deriving from restitution instead of compensation. ${ }^{, 18}$ The commentaries make clear that the provision applies 'only where there is a grave disproportionality between the burden which restitution would impose ... and the benefit which would be gained, either by the injured State or by any victim of the breach. ${ }^{19}$ The text never strays from the principle of 'full' reparation. Flexibility is introduced in how it may be achieved ${ }^{20}$ however there is no license

\footnotetext{
${ }^{14}$ Jurisdictional Immunities of the State (n 11) Judge Yusuf Dissenting Opinion, para 16.

15 ibid, para 19. See also, Basic Principles and Guidelines (n 2) art 13.

${ }^{16}$ Basic Principles and Guidelines (n 2) art 13.

${ }^{17}$ See art 42(3) of a former version of the ARS (n 9) (not retained). International Law Commission (ILC),

'Report of the International Law Commission on the Work of its 48th session' (6 May - 26 July 1996) UN Doc A/51/10, para 66 .

${ }^{18}$ ARS (n 9) art 35(b).

${ }^{19}$ ARS (n 9) Commentary to art 35, para 11.

${ }^{20}$ ARS (n 9) Commentary to art 36, para 4.
} 
to restrict the quantum or quality of reparation that is owed should the amount prove difficult on the wrongdoer.

Reparation can come in a variety of forms - material, symbolic, individual and/or collective which should be determined in light of what is most appropriate and effective to address the violations and resulting harms. Collective reparations may be appropriate to address situations in which collectives were specifically targeted (the destruction of religious or cultural property) or where the incidents which gave rise to the harm may have affected communities or large groups of persons in a similar if not identical way. Invariably, there will be a need for several forms of reparations to adequately address the harms. Experience shows that reparations processes should be highly consultative regardless of whether they are claimant led or more diffuse administrative programmes set up by governments or as part of settlement arrangements. Consultation with victim communities about their suffering, their particular wants and needs is particularly important when determining what reparations should look like, especially when it is impossible to reestablish the status quo ante, as will be the usual case with IHL violations. But victim engagement does not end there; it will be vital throughout the reparation process including during and following its implementation, if it is to empower and have meaning for the intended beneficiaries.

The reparation owed to victims may require differentiation in the awards in order to adequately account for the specificity of the harms caused to particular individuals or groups. This is important both from a compensatory perspective but also to publicly acknowledge the particular suffering of segments of society which is crucial for victims' empowerment and for peacebuilding and prevention. In addition to addressing immediate needs, reparations should also take account of any prior situations of marginalisation or discrimination or structural 
inequalities which caused or were a significant contributing factor to the violation. Reparation should have transformative potential. ${ }^{21}$

\section{Claiming Reparations for IHL Violations}

International humanitarian law (IHL) treaties are silent on whether victims can claim reparations. Unlike human rights law, IHL treaties do not specifically oblige States to afford victims a procedural remedy, nor are there specialised international complaints mechanisms. ${ }^{22}$ This may be due to the genesis of IHL as a set of rules applicable to States in their relations with each other; ${ }^{23}$ particularly on the international plane, individuals were understood as the passive recipients of protections, not active participants. Traditionally, the right to receive reparation was capable of being given effect in IHL through the laws on injury to aliens and diplomatic protection, however imperfect and discretionary the route. This passivity is out of step with human rights framings which are focused much more on agency and empowerment. Also, the passivity tends to privilege the notion of reparation as a political project over and above any notion of rights and duty bearers because it increases the uncertainty around reparations (regarding both the decision of States to claim it, and when and what is afforded). The notion of injury to aliens is also ill-suited to victims of internal armed conflict, and difficult to implement for victims who have fled their State of nationality or are otherwise unable to rely on that State to espouse their claims. The UN Claims Commission, for example, had to modify its inter-State procedures in order to allow certain

\footnotetext{
${ }^{21}$ One of the main purposes of the Nairobi Declaration on Women's and Girls' Right to a Remedy and Reparation, (19-21 March 2007). See generally, O'Rourke, Ni Aolain and Swaine, 'Transforming Reparations' (n 4).

${ }^{22}$ See J Kleffner and L Zegveld, Establishing an Individual Complaints Procedure for Violations of International Humanitarian Law' (2000) 3 Year Book of International Humanitarian Law 384, who argue that a specialised procedure should be established.

${ }^{23}$ R Dolzer, 'Settlement of War-Related Claims: Does International Law Recognize a Victim's Private Right of Action - Lessons after 1945' (2002) 20 Berkeley Journal of International Law 296, 336.
} 
international agencies to submit claims on behalf of stateless persons, who unlike other individuals could not rely on their governments to put forward claims on their behalf. ${ }^{24}$

Because of these deficiencies, there have been attempts to interpret or read in procedural rights to IHL. ${ }^{25}$ The ICRC has posited 'a growing tendency to recognise the exercise of rights by individuals, ${ }^{26}$ though it has avoided asserting this tendency as evidence of an established rule of customary international law or even an emerging one. Some commentators have sought to imply procedural rights from the fact that victims are the ultimate beneficiaries of reparation. ${ }^{27}$ The obligation to afford the result of reparation arguably requires the entity with that obligation to ensure that there are effective procedures through which the ultimate beneficiaries may gain access to reparation. ${ }^{28}$ Others have considered that the progressive evolution of human rights law has had an impact on the meaning of State responsibility and the recognition of procedural rights in the law on armed conflict. $^{29}$

\footnotetext{
${ }^{24}$ See UNCC, Guidelines relating to paragraph 19 of the Criteria for Expedited Processing of Urgent Claims (23 October 1991) UN Doc S/AC.26/1991/5, paras 3-4, specifying that 'A high number of individuals will most likely not be in a position to have their claims submitted by a Government. Among these individuals Palestinians represent the most numerous group. Furthermore, stateless persons and other individuals in the same position who still remain in Kuwait or who are situated on border lines are to be included in this category. The international community, represented by the UNCC, bears the overall responsibility for protecting the interests of the above-mentioned individuals.'

${ }^{25}$ See, eg ILC, 'Reparation for Victims of Armed Conflict' (76th ILC Conference 7-11 April, 2014) Res No $1 / 2014$, art 1 of the Resolution provides 'Victims have a right to access an effective mechanism to claim reparation ("reparation mechanism").'

${ }^{26}$ ICRC, 'Customary International Law Database' www.icrc.org/customary-ihl/eng/docs/home, accessed 10 July 2016, r 150 .

${ }^{27}$ L Zegveld, 'Remedies for Victims of Violations of International Humanitarian Law' (2003) 85 International Review of the Red Cross 497, 507; M Frulli, 'When Are States Liable Towards Individuals for Serious Violations of Humanitarian Law? The Markovic Case' (2003) 1 Journal of International Criminal Justice 406, 417. See also, Y Sandoz, 'Unlawful Damage in Armed Conflicts and Redress under International Humanitarian Law' (1982) 22 International Review of the Red Cross 131, 137; F Kalshoven, 'State Responsibility for Warlike Acts of the Armed Forces: From Article 3 of Hague Convention IV of 1907 to Article 91 of Additional Protocol I of 1977 and Beyond' (1991) 40 International and Comparative Law Quarterly 827, 835-6.

${ }^{28}$ See Bassiouni, 'International Recognition' (n 3 ) 217, who argues in relation to States' obligation to afford reparation, that, even though there is no explicit obligation to establish special procedures, those States whose existing legal frameworks are deficient must establish such procedures in order to ensure that they are capable of affording effective remedies, or else they would be implicitly violating their obligations.

${ }^{29}$ Letter dated 12 October 2000 from the President of the ICTY addressed to the Secretary-General, (3 November 2000) UN Doc S/2000/1063, para 20. See also 'Report of the International Commission of Inquiry on Darfur' (25 January 2005) www.un.org/News/dh/sudan/com_inq_darfur.pdf, accessed July 2016, para 593; Schwager and Bank, 'Is There a Substantive Right' (n 13) 378, 391; R Hoffmann, 'Reparation for Victims of
} 
Invariably though, what is recognised is States' obligation to afford reparation and victims' right to receive it, not their independent right to claim it. IHL claims lodged by victims with domestic courts have usually failed on procedural grounds, because of the perceived incompatibility with peace settlements, sovereign immunity, Act of State doctrine or the nonself-executing nature of the right to reparation under IHL. Making reference to implied rights has not helped to overcome such blockages. ${ }^{30}$

The nature of war and conflict will naturally produce extraterritorial elements. This may be because of the transnational nature of the conflict, the involvement of foreign States or multinational corporations in what might be construed as a non-international conflict, or because victims and/or perpetrators (including with their assets) may have fled to other jurisdictions. Those claims brought mainly by 'aliens' before the courts of the country said to be responsible for the violation have rarely been successful, a principle barrier being victims' lack of standing to pursue IHL claims and the non-self-executing nature of the right to reparation under IHL; ${ }^{31}$ in the USA some such claims have failed on the basis of national security confidentiality. ${ }^{32}$ When peace agreements have been negotiated by States, it is next to impossible for victims who feel aggrieved by the settlement process or for some reason fall outside the bounds of that settlement, to seek compensation before the courts of their nationality (to complain about the settlement) ${ }^{33}$ or to the courts of the wrongdoing State (to

War and Non-state Actors?' (2007) 32 South African Year Book of International Law 291, 297. See also, P Gaeta, 'Are Victims of Serious Violations of International Humanitarian Law Entitled to Compensation?' in O Ben-Naftali (ed), International Humanitarian Law and International Human Rights Law (Oxford, Oxford University Press, 2011) 310.

${ }^{30}$ Some of this jurisprudence is discussed in V Bílková, 'Victims of War and Their Right to Reparation for Violations of International Humanitarian Law' (2007) 4 Miskolc Journal of International Law 1. See also the following chapter in this volume.

${ }^{31}$ See, eg Varvarin Bridge case (10 December 2003) No 1 O 361/02 affirmed by the German Federal Constitutional Court in a decision dated 13 August 2013, BVerfG, 2 BvR 2660/06.

${ }^{32}$ El-Masri v Tenet, 437 F Supp 2d 530 (2006), para 536; 479 F 3d 296 (2007).

${ }^{33}$ See, eg the Shimoda Case, a claim brought by Japanese Hiroshima and Nagasaki residents who argued that the Japanese owed them compensation when it waived its right to seek compensation from the United States for the use of atomic bombs. The Tokyo District Court determined that ' $t$ ] here is in general no way open to an 
argue that they were not captured by the settlement) ${ }^{34}$ because the rights have been understood to vest in their State of nationality. Claims brought by victims before the courts where they are based, against a foreign State, have mainly failed for reasons of immunity. ${ }^{35}$ Exceptionally, such cases have been capable of proceeding where immunity is not at issue or where there has been specific domestic legislation allowing for a cause of action ${ }^{36}$ though judges may nevertheless bar a claim on other grounds, such as forum non conveniens or the political questions or Act of State doctrine. In some instances, the threat of pending or further suits has prompted political negotiations and settlements, benefiting large categories of victims. ${ }^{37}$ Some claims have been able to proceed on the basis of human rights law because human rights law has been deemed to apply to the conflict context (usually for conflict of a non-international character or where the State being sued is adjudged to have had effective control over the particular events in the territory). ${ }^{38}$ Furthermore, in civil law countries, where there has been a successful criminal law conviction which has opened up the possibility for civil parties to claim compensation from the convicted perpetrator. ${ }^{39}$ These cases are

individual who suffers injuries from an act of hostilities contrary to international law to claim damages on the level of international law...'. Shimoda Case (Judgment) Tokyo District Court (7 December 1963) (referred to in 'Customary International Law Database' (n 26) r 150).

${ }^{34}$ There are a few exceptions, including the Korean 'comfort women' case, where Japan was ordered to pay compensation because it had been aware of the violations but did not adopt legislation to compensate the plaintiffs. See, Ko Otsu Hei Incidents case (Judgment) Yamaguchi Lower Court (27 April 1998) [referred to in 'Customary International Law Database' (n 26) r 150].

35 Jurisdictional Immunities of the State (n 11). Note however that in the US, claims have been able to proceed against foreign state officials who are not recognised as being immune from the jurisdiction of the courts for serious violations of human rights and humanitarian law. See Samantar v Yousuf et al 130 S Ct 2278 (2010).

${ }^{36}$ In the US, several claims for damages against foreign defendants concerning IHL violations have proceeded on the basis of the Alien Tort Claims Act 28 USC, para 1350 such as Kadic v Karadzic 70 F 3d 232, 246 (1995); Mushikiwabo v Barayagwiza 1996 US Dist LEXIS 4409 (1996); Altmann v the Republic of Austria, 541 US 677 (2004); Mehinovic v Vuckovic 198 F Supp 2d 1322 (2002).

${ }^{37}$ This was the case with a number of the Holocaust-era restitution programmes set up in the 2000's. See In re Holocaust Victim Assets Litigation (2001) 2001 US App LEXIS 30154 which proceeded to settlement. See eg, Federal Law on the Establishment of a Foundation 'Responsibility, Remembrance and Future' (amended on 4 August 2001) BGBl vol 2000-I, p 1263; BGBl vol 2001-I, p 2036.

${ }^{38}$ Jaloud $v$ the Netherlands (App no 47708/08) ECHR 20 November 2014; Al-Jedda $v$ the United Kingdom (App no 27021/08) ECHR 7 July 2011; Al-Skeini and ors, Bar Human Rights Committee (intervening) and ors (intervening) $v$ United Kingdom (2011) 53 EHRR 18; Al-Saadoon and Mufdhi $v$ the United Kingdom (App no 61498/08) ECHR 2 March 2010.

${ }^{39} \mathrm{See}$, eg for a sampling of claims in the countries where the violations took place: Chad: Criminal Trial Judgment relating to 20 security agents and accompanying civil action for damages, N'Djaména, (25 March 2015); Democratic Republic of the Congo: Military Prosecutor v Massaba (Blaise Bongi) RP No 018/2006, 
important in that the victims can rely at least in part on the prosecutor to prove the main facts of the case; however the victims are dependent on there being a conviction to pursue the civil claims.

International claims procedures have been established in response to IHL violations, such as (in response to international armed conflicts) the Treaty of Versailles ${ }^{40} \mathrm{UN}$ Compensation Commission, ${ }^{41}$ Ethiopia Eritrea Claims Commission, ${ }^{42}$ and numerous Holocaust-era restitution programmes. Numerous property restitution commissions ${ }^{43}$ have been instituted to resolve claims and compensation schemes have been put in place by governments at the end of an internal armed conflict. For example, the Colombian Justice and Peace Law of 2005 provides extensive provisions for reparations by demobilised paramilitaries, and following a decision of the Colombian Constitutional Court, also by the State. ${ }^{44}$ Reparation to Colombian conflict victims has also been a prominent feature of jurisprudence of the Inter-American Court of Human Rights. ${ }^{45}$ Often these measures are partial, only applying to certain categories of conflict victims or to crimes which took place within an overly narrow timeframe. At times, measures have also been found to be exclusionary to women and other marginalized groups.

RMP No 242/PEN/06, ILDC 387 (24 March 2006); Peru: Sentencia Alberto Fujimori Exp. No. AV-19-2001 (7 April 2009). For extraterritorial claims, see The Netherlands: The Netherlands v Mpambara 22-002613-09 (2011); Norway: The Public Prosecuting Authority v Mirsad Repak 08-018985MED-OTIR/08 (2008); Senegal: Case against Hissein Habré (Decision on civil party claims) (29 July 2016).

${ }^{40}$ Treaty of Peace Between the Allied and Associated Powers and Germany (adopted 28 June 1919, entered into force 10 January 1920) 225 CTS 188 (Treaty of Versailles) art 297(e).

${ }^{41}$ See, UNCC, 'Arrangements for Ensuring Payments to the Compensation Fund' (2 August 1991) UN Doc S/AC.26/1991/1, para 14.

${ }^{42}$ Agreement between the Government of the State of Eritrea and the Government of the Federal Democratic Republic of Ethiopia (adopted 12 December 2000, entered into force 12 December 2000) 2138 UNTS 94, 40 ILM 260, art 5.

${ }^{43}$ International Organization for Migration (IOM), 'Property Restitution and Compensation: Practices and Experiences of Claims Programmes' (2008) Ref no 978-92-9068-450-3.

${ }^{44}$ Corte Constitucional, Sentencia C-370/06, Gaceta de la Corte Constitucional (18 May 2006) www.corteconstitucional.gov.co/relatoria/2006/c-370-06.htm, accessed 31 July 2016.

${ }^{45}$ See, eg Mapiripán Massacre v Colombia (Merits, Reparations and Costs) Inter American Court of Human Rights Series C No 134 (15 September 2005), paras 355.7-355.17; 19 Merchants $v$ Colombia (Merits, Reparations and Costs) Inter American Court of Human Rights Series C No 109 (5 July 2005), paras $283-84$. 
The degree of claimant engagement within these bodies has also varied. In some processes, injured individuals have no procedural involvement. In others, victims have been consulted usually in groups as to the harm suffered and their preferences for reparation, with or without needing to submit verifiable proof of individualised harm. In yet other instances, more rigorous processes have been established in which injured individuals may make a claim to an administrative procedure established precisely for that purpose or a court.

More simplified approaches tend to be taken when there is a large number of injured individuals who would be entitled to significant reparation that would be overwhelming for a court to adjudicate claim by claim, and/or when the nature of the violations is such that victims would not have the requisite proof to satisfy a court of their injuries using typical standards of proof. ${ }^{46}$ These can be accompanied by processes which assign the secretariats of the claims commissions the task of gathering evidence to substantiate or corroborate the evidence supplied by applicants. For instance, the Legal Unit of the Commission for Real Property Claims of Refugees and Displaced Persons in Bosnia and Hercegovina amassed cadastre and property book records to verify the claims of applicants, in recognition of the difficulties that would be posed should they be required to collect this data from local municipalities directly. ${ }^{47}$ Similarly, the lawyers and paralegals working at the secretariat of the first Claims Resolution Tribunal for Dormant Accounts in Zurich, Switzerland conducted legal and factual inquiries as well as historical research on the circumstances surrounding a

\footnotetext{
${ }^{46}$ See generally, HM Holtzmann and E Kristjánsdóttir (eds), International Mass Claims Processes: Legal and Practical Perspectives (Oxford, Oxford University Press, 2007); M Bazyler and R Alford (eds), Holocaust Restitution: Perspectives on the Litigation and its Legacy (New York, New York University Press, 2006); P Hayner, Unspeakable Truths: Transitional Justice and the Challenge of Truth Commissions, 2nd edn (New York, Routledge 2010); E Kristjánsdóttir, 'International Mass Claims Processes and the ICC Trust Fund for Victims' in C Ferstman, et al (eds), Reparations for Victims of Genocide, War Crimes and Crimes against Humanity: Systems in Place and Systems in the Making (Leiden, Martinus Nijhoff, 2009) 170; M Henzelin, V Heiskanen and G Mettraux, 'Reparations to Victims before the International Criminal Court: Lessons From International Mass Claims Processes' (2006) 17 Criminal Law Forum 317.

${ }^{47}$ See C Ferstman and SP Rosenberg, 'Reparations in Dayton's Bosnia and Herzegovina', in Ferstman et al, Reparations for Victims of Genocide (n 46) 483.
} 
case, and often sent requests for (additional) information to the bank or the claimant to inquire about information on the account and the account owner contained in the bank records or to inquire about and clarify specific aspects of a claim. ${ }^{48}$

The recent practice of international or internationally-supported criminal courts that allows victims to apply for reparation upon a conviction of an individual perpetrator is an important procedural development, though both the procedures and the outcomes have proved to be highly restrictive thus far. ${ }^{49}$ Given the subject matter jurisdiction of the International Criminal Court, reparations will only be afforded for crimes within the jurisdiction of the Court (genocide, war crimes, crimes against humanity and, potentially, aggression) and not all violations which occur in conflict. Furthermore, access to reparations will be predicated upon the nature of the charges pursued by the Prosecutor. To date, this has posed a significant limitation on victims' access to Court-ordered reparations, as has the limited funds secured through fines and forfeitures, and raised through voluntary contributions to the ICC's Trust Fund.

\section{The Award of Reparations}

The substantive component of reparations - the obligation of States to afford reparations, is reflected in several international humanitarian law treaties, particularly Article 3 of the Hague Convention IV ${ }^{50}$ largely reproduced in Article 91 of Protocol I. ${ }^{51}$ It stems from the

\footnotetext{
${ }^{48} \mathrm{H}$ Niebergall, 'Overcoming Evidentiary Weaknesses in Reparation Claims Programmes - The Mass Claims Context', in Ferstman et al, Reparations for Victims of Genocide (n 46) 145.

${ }^{49}$ Rome Statute of the International Criminal Court (adopted 17 July 1998, entered into force 1 July 2002) UN Doc A/CONF 183/9 (ICC Statute) art 75; Internal Rules of the Extraordinary Chambers in the Courts of Cambodia (9 February 2009, amended 17 September 2010) www.eccc.gov.kh/en/document/legal/internal-rules, accessed July 2016, r 23.

${ }^{50}$ Hague Convention No IV Respecting the Laws and Customs of War on Land and its annex: Regulations concerning the Laws and Customs of War on Land (adopted 18 October 1907, entered into force 26 January 1910) 36 Stat 2227 TS No 539 (Hague Convention IV) art 3.
} 
general obligation of States to afford reparation for internationally wrongful acts, as reflected in the International Law Commission's Articles on the Responsibility of States for Internationally Wrongful Acts. ${ }^{52}$ This approach has been followed by the International Court of Justice in its Wall Advisory Opinion, where it held that Israel was obliged 'to make reparation for all damage caused by the construction of the wall' 'to all the natural or legal persons concerned ${ }^{53}$ as a result of the various international obligations that Israel was said to have breached. ${ }^{54}$ Thus, reparation is premised on the existence of a legal violation, and not simply on the existence of an injury. Consequently there is no obvious obligation under this framework to afford reparation to victims for 'legal' collateral damage during armed conflict. ${ }^{55}$ This is despite the introduction of strict liability frameworks in other areas of the law. ${ }^{56}$

The International Committee of the Red Cross (ICRC) has expressed the view that the State obligation to afford reparation for IHL violations constitutes a rule of customary international law, applicable in both international and non-international armed conflicts. ${ }^{57}$ The same view was expressed in the final report of the International Commission of Inquiry on Darfur. ${ }^{58}$ This

\footnotetext{
${ }^{51}$ Protocol I Additional to the Geneva Conventions of 12 August 1949 and relating to the Protection of Victims of International Armed Conflicts (adopted 8 June 1977, entered into force 7 December 1978) 1125 UNTS 3 (API).

${ }^{52}$ ARS (n 9) arts 1, 12; Case concerning the factory at Chorzow (Gerv Pol) (Jurisdiction) PCIJ Sr A No 9, para 21. See also EC Gillard, 'Reparation for Violations of International Humanitarian Law' (2003) 85 International Review of the Red Cross 532.

${ }^{53}$ Legal Consequences of the Construction of a Wall (n 8) para 152.

54 ibid, para 147.

${ }^{55}$ However, many troops have a practice of giving discretionary one off payments without an admission of liability when civilians are killed or injured in the course of hostilities. For a review of such practices, see Center for Civilians in Conflict, 'Monetary Payments for Civilian Harm in International and National Practice', (2013).

${ }^{56}$ See, eg ILC 'International Liability for Injurious Consequences Arising out of Acts not Prohibited by International Law' legal.un.org/ilc/guide/9.shtml, accessed July 2016.

57 'Customary International Law Database' (n 26) r 150.

${ }^{58}$ International Commission of Inquiry on Darfur, 'Report of the International Commission of Inquiry on Darfur' (25 January 2005) www.un.org/News/dh/sudan/com_inq_darfur.pdf, accessed 24 July 2016, paras 76, 592, 593. Note however that the compensation commission the Commission of Inquiry recommended was never established. For a contrary view on the law, see C Tomuschat, 'Darfur - Compensation for the Victims' (2005) 3 Journal of International Criminal Justice 579.
} 
is consistent with the approach taken by the ILC, which underscores that the reparations obligation automatically attaches to all internationally wrongful acts; it does not distinguish between international or non-international armed conflicts. ${ }^{59}$ However, the status of the rule is controversial, owing to the limited and variable practice, typically contingent on States' interests and settlement prerogatives. The rule has been particularly controversial for noninternational conflicts, given that no compensatory obligation was included in Protocol II. ${ }^{60}$ Yet, a failure to recognise the reparations obligation in internal armed conflict may create discrepancies with other applicable law, given the significant if not complete overlap with non-derogable human rights obligations operating in such contexts.

With respect to international armed conflicts, compensation has typically been dealt with at the inter-State level in multilateral or bilateral peace treaties or settlement agreements through token lump-sum amounts which had little or no correlation with the precise scale of the damages and harm caused to individual victims, in spite of the general international law standard requiring restitutio ad integrum. ${ }^{61}$ As Kalshoven has noted, 'the agreements usually lay an obligation on the vanquished State to pay a more or less random amount, determined more by its perceived financial capabilities than by any serious attempt to assess the damage caused by the unlawful acts of either party's armed forces; and the victor State may or may not distribute (part of) the money to individual claimants' ${ }^{62}$ They emphasise cy-pres remedies, lump-sum payments to a large number of individuals calculated along the line of specific beneficiary groups, symbolic and communitarian (as opposed to individual) forms of reparation determined by judicial, quasi-judicial or non-judicial mechanisms. 'Full' reparation is not afforded because it is unrealistic - the compensable amount would be too

\footnotetext{
${ }^{59}$ ARS (n 9) art 31.

${ }^{60}$ Protocol II Additional to the Geneva Conventions of 12 August 1949 and relating to the Protection of Victims of Non-International Armed Conflicts (adopted 8 June 1977, entered into force 7 December 1978) 1125 UNTS 609 (APII).

${ }^{61}$ ARS (n 9).

${ }^{62}$ Kalshoven, 'State Responsibility for Warlike Acts' (n 27) 836.
} 
high, there would be too many victims to repair, or because it is politically undesirable in the context of the end of the conflict. ${ }^{63}$ At times, treaties deliberately exclude or settle claims. ${ }^{64}$

Courts or formal adjudicative bodies that have considered reparation for violations occurring in the context of an international armed conflict are limited. The International Court of Justice has adjudicated IHL violations in a number of its cases; however, remedies have usually been left to the parties to decide after a finding of a violation. This occurred with the case Armed Activities on the Territory of the Congo (Democratic Republic of the Congo $v$. Uganda), which the ICJ decided on the merits in December $2005 .{ }^{65}$ The Court found in the DRC's favour, holding that Uganda had violated the principles of non-use of force and nonintervention, as well as its obligations under international human rights law, international humanitarian law, and the other obligations incumbent upon it under international law. In particular, it held that Uganda's responsibility was engaged in respect of the wrongful acts of the Ugandan military as well as for any lack of vigilance in preventing violations of human rights and international humanitarian law by other actors present in the territory that Uganda occupied, including by rebel groups acting on their own account. In relation to a counterclaim brought by Uganda, the ICJ determined that the DRC had breached the 1961 Vienna Convention on Diplomatic Relations in a variety of ways, including when its military attacked the Ugandan Embassy in Kinshasa and maltreated Ugandan diplomats and others on the embassy premises and the international airport. Both parties were obligated to afford reparation. The Court decided that, failing agreement between the parties, it would settle the question of reparation due to each of them, and reserved for that purpose the subsequent procedure in the case.

\footnotetext{
${ }^{63}$ ICRC, 'Strengthening Legal Protection for Victims of Armed Conflicts' (28 November - 1 December 2011) Doc No 31IC/11/5.1.1, p 27.

${ }^{64}$ Considered in Dolzer, 'Settlement of War-Related Claims' (n 23).

${ }^{65}$ Armed Activities on the Territory of the Congo (Democratic Republic of the Congo v Uganda) [2005] ICJ Rep 168.
} 
The DRC finally came back to the Court a decade later, ${ }^{66}$ and the matter remains pending. In his declaration, Judge Cançado Trindade noted that this lapse of time 'already far exceeded a reasonable time, bearing in mind the situation of the victims, still waiting for justice' [para. 3]. He argued that the judgment should have been accompanied by the determination of a reasonable time limit for the provision of reparations for damages inflicted upon the victims. Unfortunately however, there is currently no framework in place to ensure that those ultimate intended beneficiaries will benefit in any concrete way from reparations awarded in an interState process; regardless of how long that process will take. When reparations are awarded against several parties to a conflict, the reparations of each party tend to simply cancel each other out. Such was the case with the Eritrea-Ethiopia Claims Commission, which painstakingly reviewed the quantum and quality of numerous IHL violations of both parties, amongst other violations. ${ }^{67}$ Because reparation is afforded to a State under the principle of injury to aliens, the reparation is owed formally to the State, not the individuals, even if the individuals are the ultimate intended beneficiaries.

Similarly, those international criminal courts and tribunals that allow reparation claims have not privileged the concept of 'full' reparation; quite the opposite, judgments to date have emphasised that, given the sui generis statutory or rules frameworks, and taking into account the numbers of potential beneficiaries and often impecunious convicted perpetrators, a

\footnotetext{
${ }^{66}$ Armed Activities on the Territory of the Congo (Democratic Republic of Congo v Uganda) (Order) [2015] Gen List no 116.

${ }^{67}$ Writing about the Ethiopia and Eritrea Claims Commission, Murphy, Kidane and Snider note that the approximately $\$ 161.5$ million awarded to Eritrea and approximately $\$ 174$ million awarded to Ethiopia were not implemented nor were they likely to be implemented. They set out some of the rather limited steps undertaken by the Commission to encourage the parties to implement the awards, however these were not heeded, and recommend a number of ways in which courts, commissions or similar bodies could strengthen the prospects for reparations to be paid, and for the reparations to reach their ultimate intended beneficiaries. See SD Murphy, W Kidane, TR Snider, Litigating War: Mass Civil Injury and the Eritrea-Ethiopia Claims Commission (Oxford, Oxford University Press, 2014) 407-410.
} 
'collective' or symbolic approach should be taken. ${ }^{68}$ At the time of writing, bureaucratic wrangling at the International Criminal Court about reparations has meant that four years after the Court's first decision on reparations in the Lubanga case, not a single victim has benefited from court-ordered reparations. ${ }^{69}$

With respect to conflicts of a non-international character, reparations are sometimes included in the mandate of transitional justice processes, such as compensation or land restitution commissions or specialised government programmes which undertake vetting, establish new institutions, contribute to truth-telling and memorialisation or provide victims with access to rehabilitation and health services, pensions or other benefits. In these cases, the adequacy of the adopted measures tends to depend on the degree of victim engagement, the transparency of decision-making and inclusiveness of the process (fairness and non-discrimination). Some processes have been inaccessible to victims outside of the country or to non-citizens; at times processes have required victims to undertake onerous procedural steps to comply or have taken a narrow view of victimisation which has led to the exclusion of entire categories of victims from the programme. Occasionally, victims have sought to address the weaknesses or inadequacies of such reparations programmes through the courts or through sustained advocacy. Sometimes this has led to improvements or additions.

In civil law countries where individual perpetrators have been prosecuted and reparations have been awarded as part of civil damages adhesion processes, the reparation payments often remain unimplemented. This is because individual perpetrators are often impecunious or in instances when an award is made jointly and severally against the individual perpetrator

\footnotetext{
${ }^{68}$ Prosecutor v Thomas Lubanga Dyilo (Appeal on Reparations) ICC-01/04-01/06-3129 (3 March 2015); CoProsecutors $v$ Kaing Guek Eav alias Duch, (Appeal Judgment) 001/18-07-2007-ECCC/SC (2 February 2012) 281-320, $630-717$.

${ }^{69}$ Prosecutor v Thomas Lubanga Dyilo (Request Concerning the Feasibility of Applying Symbolic Collective Reparations) ICC-01/04-01/06-3219 (15 July 2016).
} 
and the State, the procedures to enforce claims against the State have been unwieldy and inaccessible. ${ }^{70}$ In Chad, a local criminal court convicted 20 former members of the security service in March 2015 and ordered that 7,000 victims be compensated (a total amount of 75 billion CFA). The Chadian Government was ordered to contribute half the funds but at the time of writing, no progress had been made with the release of funds or establishment of a commission to oversee payment.

\section{Forms of Reparation}

The Articles on the Responsibility of States identify cessation, assurances and guarantees of non-repetition, and reparation, which may take the form of restitution, compensation, or satisfaction. ${ }^{71}$ This is consistent though somewhat more narrowly framed that the Basic Principles and Guidelines, which refer to restitution, compensation, rehabilitation, satisfaction and guarantees of non-repetition.

\section{$\underline{\text { Restitution }}$}

Restitution is understood in most IHL treaties as the main obligation, failing which compensation or other forms of reparation should be afforded. ${ }^{72}$ It is a particularly relevant and important component of reparation for conflict violations. The restoration of citizenship, the return of land and property or assets, the release of prisoners - all forms of restitution, are

\footnotetext{
${ }^{70}$ See, eg SA v the Democratic Republic of the Congo, claim filed with the African Commission on Human and Peoples' Rights (21 November 2014) www.redress.org/downloads/engcommunication-sa-v-drc20-nov2014.pdf, accessed 25 July 2016. See also REDRESS et al, 'Right to Reparation for Survivors: Recommendations for Reparation for Survivors of the 1994 Genocide against Tutsi' (October 2012) www.redress.org/downloads/publications/121031right_to_rep.pdf, accessed 25 July 2016.

${ }^{71}$ ARS (n 9) arts 30(a), 30(b), 31.

${ }^{72}$ See, eg Geneva Convention I for the Amelioration of the Condition of the Wounded and Sick in Armed Forces in the Field (adopted 12 August 1949, entered into force 21 October 1950) 75 UNTS 31 (GC I) arts 34, 35; Geneva Convention IV Relative to the Protection of Civilian Persons in Time of War (adopted 12 August 1949, entered into force 21 October 1950) 75 UNTS 287 (GC IV) art 55; Protocol for the Protection of Cultural Property in the Event of Armed Conflict (adopted 14 May 1954, entered into force 7 August 1956) 249 UNTS 358, art 3; UNHCR, Guiding Principles on Internal Displacement (Geneva1998) UN Doc E/CN.4/1998/53/Add.2, principle 29(2); Convention for the Protection and Assistance of Internally Displaced Persons in Africa (adopted 22 October 2009, entered into force 6 December 2012) art 12.
} 
key means by which those that have been displaced or otherwise affected by conflict can begin to resume their lives. Restitution in some of these areas has the potential to be transformative: for instance land, property and succession laws that restrict female inheritance have sometimes been changed in post-conflict contexts. ${ }^{73}$

IHL treaties include the need to ensure that transferred detainees receive appropriate treatment, failing which the transferring authority has the obligation to 'take effective measures to correct the situation or shall request the return of the prisoners of war' ${ }^{74}$ They also make specific reference to the requirement to return requisitioned property at the end of a war, failing which, compensation is required. ${ }^{75}$ Similar restitution obligations are mentioned in the Convention for the Protection of Cultural Property and its first protocol. ${ }^{76}$ With respect to refugees and displaced persons, the obligation to facilitate return and assist them to recover property is also a primary objective, failing which compensation or other forms of reparation may sometimes be acceptable alternatives. ${ }^{77}$

There are numerous examples of post-conflict restitution. Sometimes restitution has been incorporated into peace settlements, such as to address mass displacement, as occurred in

\footnotetext{
${ }^{73}$ See, eg Centre on Housing Rights and Evictions, 'Promoting and Protecting the Inheritance Rights of Women: A Survey of Law and Practice in Sub-Saharan Africa' (2004).

${ }^{74}$ Geneva Convention III Relative to the Treatment of Prisoners of War (adopted 12 August 1949, entered into force 21 October 1950) 75 UNTS 135 (GC III) art 12.

${ }^{75}$ Eg GCI, arts 34, 35; GCIV, art 55. For a judicial determination on the obligation to restitute cultural sites, see The Islamic Community in Bosnia and Herzegovina v The Republika Srpska (Decision on Admissibility and Merits) CH/96/29 (11 June 1999) and The Islamic Community of Bosnia and Herzegovina ('Prnjavor Graveyard') CH/99/2177 (February 2000). These decisions and the challenges with their implementation are discussed in Ferstman and Rosenberg, 'Reparations in Dayton's Bosnia and Herzegovina' (n 47) 495-498. ${ }^{76}$ Convention for the Protection of Cultural Property in the Event of Armed Conflict (adopted 14 May 1954, entered into force 7 August 1956) 249 UNTS 240, art 18(b); Protocol for the Protection of Cultural Property (n 72) art 3. The obligation to return cultural property is set out in several UN Security Council resolutions, such as UNSC Res 686 (2 March 1991) UN Doc S/RES/686, para 2(d); Res 1483 (22 May 2003) UN Doc S/RES/1483, para 7; Res 2199 (12 February 2015) UN Doc S/RES/2199, para 17. In contrast, the Second Protocol to the Hague Convention of 1954 for the Protection of Cultural Property in the Event of Armed Conflict (adopted 26 March 1999, entered into force 4 March 2004) 38 ILM 769 reinforces the obligation to prevent the destruction of cultural property and adopts a framework for individual criminal responsibility.

${ }^{77}$ Guiding Principles on Internal Displacement (n 72) principle 29(2); Convention for the Protection and Assistance of Internally Displaced Persons (n 72) art 12.
} 
Bosnia and Hercegovina. ${ }^{78}$ In other cases, restitution has been pursued by States at the end of an international conflict, particularly when the property or assets are State owned, such as the return of stolen cultural property or to delimit the boundary of States' territories. ${ }^{79}$

Restitution of private-owned property such as art, homes, bank accounts, or the restoration of private rights such as citizenship has at times been initiated by claimant litigation. These cases however can be plagued by lack of documentation evidence of ownership lost in the conflict and its aftermath and the vagaries of the passage of time. Property and assets cases are further complicated by determinations as to whether any sale from the original owner was a product of duress, and whether any subsequent sales to bona fide parties give rise to legal interests on their part that must be taken into account. Looted art cases, for instance will often turn on which country's law is being applied, given significant differences in how limitation periods are calculated and applied, and the rules concerning the rights of bona fide purchasers. This has led to several attempts at standardisation across jurisdictions. ${ }^{80}$ It also suggests a need for special procedures to be employed, to avoid the excessive formalism of courts which are not always best placed to take account of the limitations of victims' evidence.

Occasionally restitution claims have resulted not only in the settlement of an individual's claim but in agreements for much wider restitution programmes covering large classes of beneficiaries. Restitution may also result from advocacy as part of wider processes of

\footnotetext{
${ }^{78}$ See Annex 7 of the General Framework Agreement for Peace in Bosnia and Herzegovina (the Dayton Peace Agreement) 21 November 1995 which affirmed the right of refugees and displaced persons to have their property restored to them (or to be compensated where restitution is not possible) and included the general responsibility to create 'conditions suitable for return' such as the repeal of discriminatory laws and prevention of incitement of ethnic hostility.

${ }^{79}$ Agreement between the Government of the State of Eritrea and the Government of the Federal Democratic Republic of Ethiopia (Algiers Agreement) 12 December 2000 (2001) 40 ILM 260.

${ }^{80}$ See, eg Unidroit Convention on Stolen or Illegally Exported Cultural Objects (Rome, 24 June 1995); Washington Conference Principles on Nazi-Confiscated Art (Washington DC 3 December 1998); Holocaust Expropriated Art Recovery Act of 2016 (114th Congress 2015-2016) introduced 7 April 2016.
} 
transition within a country. Where done well, restitution can also complement wider development goals, particularly in the area of land and property where security of tenure can be strengthened through such processes.

Victims have sometimes used the courts to complain about the adequacy and fairness of restitution programmes, which have occasionally been found to discriminate against certain potential beneficiary groups. ${ }^{81}$ Such complaints have not always been successful, however. The European Court of Human Rights has dismissed claims relating to the inadequacy of State administrative compensation schemes (which had the effect of extinguishing private claims relating to Nazi slave labour), on the basis that the State should have a wide margin of appreciation to strike an appropriate balance in the general interest. ${ }^{82}$

The European Court of Human Rights has considered a number of cases in which individuals have been dispossessed of property and other assets as a result of conflict. ${ }^{83}$ Chiragov v. Armenia concerned an application brought by Azerbaijani Kurds who were forced to flee from their homes to Baku in the context of the Nagorno-Karabakh conflict. They have since been unable to return to their homes and properties because of Armenian occupation. The Grand Chamber, in finding for the Applicants noted that 'it would appear particularly important to establish a property claims mechanism, which should be easily accessible and provide procedures operating with flexible evidentiary standards, allowing the applicants and others in their situation to have their property rights restored and to obtain compensation for the loss of their enjoyment. ${ }^{84}$ Restitution programmes to redress both Holocaust-era injustices and subsequent nationalisation programmes put in place under communist rule

\footnotetext{
${ }^{81}$ Ivica Kevesevic $v$ the Federation of Bosnia and Herzegovina CH/97/46 (10 September1998); García Lucero et al $v$ Chile (Preliminary objection, merits and reparations) (28 August 2013).

${ }^{82}$ Poznanski and others v Germany (Decision on Admissibility) (App no 25101/05) ECHR 3 July 2007.

${ }^{83}$ Principal among these is Loizidou and Cyprus (intervening) v Turkey (1997) 23 EHRR 513.

${ }^{84}$ Chiragov and Others $v$ Armenia (App no 13216/05) ECHR 16 June 2015, para 199.
} 
have had less success, given that the Court's restrictive interpretation of its temporal jurisdiction has barred the majority of claims regarding the unlawful expropriations, considering only the fairness of the later restitution procedures. ${ }^{85}$

\section{Compensation}

Compensation is understood to cover any financially assessable damage both material and moral and loss of profit, ${ }^{86}$ as well as the costs for legal or expert assistance, medicine, and psychological and social services. ${ }^{87}$ Under international humanitarian law, protections afforded to individuals (and concomitant rights to reparation when the protections are breached) are determined according to their nationality (citizen, enemy citizen, neutral party's citizen) and status (civilian or combatant). Article 3 of the Hague Convention IV as well as Article 91 of Protocol 1 refer to compensation, 'if the case demands', which is understood to require compensation if and when restitution is impossible. ${ }^{88}$

Compensation 'should be provided for any economically assessable damage, as appropriate and proportional to the gravity of the violation and the circumstances of each case..., such as: (a) physical or mental harm; (b) lost opportunities, including employment, education and social benefits; (c) material damages and loss of earnings, including loss of earning potential; (d) moral damage; (e) costs required for legal or expert assistance, medicine and medical services, psychological and social services. ${ }^{89}$ As was held by the Inter-American Court of Human Rights in the Velásquez Rodríguez case, 'it is appropriate to fix the payment of 'fair

\footnotetext{
${ }^{85}$ See, eg Malhous $v$ the Czech Republic (App no 33071/96) ECHR 13 December 2000.

${ }^{86}$ ARS (n 9) art 36.

${ }^{87}$ Basic Principles and Guidelines (n 2) art 20.

${ }^{88}$ API, art 91; ICRC, ' 1949 Conventions and Additional Protocols, and their Commentaries - Commentary to Art 91’ www.icrc.org/applic/ihl/ihl.nsf/vwTreaties1949.xsp, accessed 24 July 2016.

${ }^{89}$ Basic Principles and Guidelines (n 2) art 20.
} 
compensation' in sufficiently broad terms in order to compensate, to the extent possible, for the loss suffered. ${ }^{90}$

Judicial reparations processes tend to privilege compensation over other forms of reparation, although, as indicated earlier in this chapter, compensation has rarely been 'full'.

\section{$\underline{\text { Rehabilitation }}$}

Rehabilitation includes measures for physical and psychological treatment ${ }^{91}$ as well as legal and social services, ${ }^{92}$ and access to social benefits. ${ }^{93}$ Certain specialist thematic IHL conventions emphasise the importance of targeted victim assistance and rehabilitation, such as the Convention on Cluster Munitions. ${ }^{94}$ The Optional Protocol to the Convention on the Rights of the Child on the involvement of children in armed conflict" ${ }^{95}$ specifies that 'States Parties shall take all feasible measures to ensure that persons within their jurisdiction recruited or used in hostilities ... are demobilized or otherwise released from service. States Parties shall, when necessary, accord to such persons all appropriate assistance for their physical and psychological recovery and their social reintegration. ${ }^{96}$ It also indicates that 'States Parties shall cooperate ... in the rehabilitation and social reintegration of persons who are victims of acts contrary thereto, including through technical cooperation and financial assistance. ${ }^{97}$

\footnotetext{
${ }^{90}$ Case of Velásquez Rodríguez v Honduras (Interpretation of the Compensatory Damages) Inter American Court of Human Rights Series C no 9 (17 August 1990) para 27.

${ }^{91}$ Plan de Sánchez Massacre v Guatemala (Reparations) Inter American Court of Human Rights Series C no 116 (19 November 2004) paras 106-8.

${ }^{92}$ Basic Principles and Guidelines (n 2) art 21.

${ }^{93}$ UN Human Rights Committee, 'Concluding observations on the second periodic report of Bosnia and Herzegovina, adopted by the Committee at its 106th session (15 October-2 November 2012)' (13 November 2012) UN Doc CCPR/C/BIH/CO/2, para 8.

${ }^{94}$ See Convention on Cluster Munitions (adopted 30 May 2008, entered into force 1 August 2010) 2688 UNTS 39 , art 3.

${ }^{95}$ Optional Protocol to the Convention on the Rights of the Child on the Involvement of Children in Armed Conflict (adopted 25 May 2000, entered into force 12 February 2002) 2173 UNTS 222.

96 ibid, art 6.

97 ibid, art 7.
} 
Rehabilitation has been awarded or confirmed by the Inter-American Court of Human Rights in a number of cases relating to conflict victims. For instance in the Barrios Altos case against Peru, which resulted in an agreement on reparations between the parties, Peru agreed to cover the health expenses of the beneficiaries, granting them free care at the respective health centre, in respect of diagnostic procedures, medicine, hospitalisation, surgery, childbirth, traumatological rehabilitation, and mental health. ${ }^{98}$ In other cases, the Court has taken a broader approach to rehabilitation, incorporating not only health rehabilitation, but also housing and educational programmes. ${ }^{99}$ The International Criminal Court's Trust Fund for Victims has emphasised rehabilitation as part of its assistance work with victims of crimes coming within the jurisdiction of the Court. It has reported on both psychological and emotional support and physical rehabilitation work, including referrals for medical care, orthopaedic or plastic surgery, fitting of prostheses, treatment of wounds or infections, fistula treatment and other types of care. ${ }^{100}$

\section{$\underline{\text { Satisfaction and Guarantees of Non-Repetition }}$}

Mass victimisation is the norm for both international and international armed conflicts. As indicated, 'full' reparations, the clear standard for inter-State claims set out in the Articles on State Responsibility, have not been capable of implementation in practice. This is made worse in contexts when particular victims' situations of vulnerability or marginalisation preclude them from benefiting fully from any reparations offered, or results in an unjust distribution of reparations.

\footnotetext{
${ }^{98}$ Barrios Altos v Peru (Reparations and Costs) Inter American Court of Human Rights Series C No 87 (30 November 2001), para 42. See also, Cantoral Benavides v Peru (Reparations and Costs) Inter American Court of Human Rights Series C No 88 (3 December 2001), para 51(b); Molina Theissen v Guatemala (Reparations and Costs) Inter American Court of Human Rights Series C No 108 (3 July 2004), paras 58 (2), 71.

${ }^{99}$ See, eg Moiwana v Suriname (Preliminary Objections, Merits, Reparations and Costs) Inter American Court of Human Rights Series C No 124 (15 June 2005), paras 213-15; Yakye Axa v Paraguay (Merits, Reparations and Costs) Inter American Court of Human Rights Series C No 125 (15 June 2005), paras 205-206, 221. ${ }^{100}$ ICC Trust Fund for Victims, 'Programme Progress Report' (2015) 17-18.
} 
The challenges posed by mass victimisation are also evident when it comes to determining what forms of reparation are most suitable. It is not obvious how to adapt individual remedies to the context of mass victimisation when it is often claimed that collective reparations, particularly in the area of satisfaction and guarantees of non-repetition, might be better suited to balance individual and collective interests. Collective reparations can be problematic when the beneficiaries do not see themselves as a collective, either because they are dispersed or because of the nature of the violation. Even when the violation was perpetrated against a community or group, designing reparations (whether judicial or administrative) can also present challenges, as there is risk of compounding stereotypes, confounding reparations with development or appearing tokenistic.

Satisfaction, understood as an exceptional remedy in the Articles on the Responsibility of States, has been frequently ordered in human rights jurisprudence to address injuries which involve breaches of trust, which acknowledgement and commemoration may help to remedy. Satisfaction has been awarded by courts and recommended by treaty bodies considering an array of violations occurring in the context of conflict. For instance, it was the remedy, and controversially the sole remedy (in the form of a declaration of responsibility), awarded by the International Court of Justice against Serbia for its failure to prevent genocide in the Bosnia Genocide case. ${ }^{101}$

Criminal investigations have also been ordered as a form of satisfaction; ${ }^{102}$ amnesties and related procedural bars on investigations and prosecutions have been disallowed for many crimes occurring during (and outside of) conflict, including genocide, war crimes, crimes

\footnotetext{
${ }^{101}$ Application of the Convention on the Prevention and Punishment of the Crime of Genocide (Bosnia and Herzegovina v Serbia and Montenegro) (Merits) [2007] ICJ Rep 43, para 463.

${ }^{102}$ Bassiouni, 'International Recognition' (n 3) 263-264.
} 
against humanity, torture, enforced disappearances. ${ }^{103}$ Cessation, as a form of satisfaction, has been emphasised as a remedy for continuing violations such as disappearances, wherein full disclosure of the truth, public acts of recognition and the need to locate and identify remains are understood as central to satisfaction. ${ }^{104}$ What constitutes meaningful and appropriate satisfaction in response to an IHL violation requires decision-makers to consult with the widest possible constellation of victims.

Guarantees of non-repetition have included creating specific obligations to prevent new violations, ${ }^{105}$ strengthening the administration of justice, improving monitoring mechanisms and other procedural safeguards, changing policies or legislation, vetting public officials and setting up new institutions and commissions of inquiry. ${ }^{106}$ These measures are most meaningful when they respond specifically to marginalisation or structural inequalities operating in society and actively seek to break discriminatory patterns.

Guarantees of non-repetition are also linked with general measures of deterrence and prevention of future violations. For instance, UN Security Council Resolution 2199 of 12 February 2015 recognised the link between financial sanctions, bans on the trade in arms, oil, and Iraqi and Syrian looted cultural property and the disruption of armed groups and the prevention of terrorism.

\footnotetext{
${ }^{103}$ Bautista de Arellana v Colombia (1995) Human Rights Committee, CCPR/C/55/D/563/1993, paras 8.2, 10. ${ }^{104}$ Neira-Alegría v Peru (Reparations and Costs) Inter American Court of Human Rights Series C No 29 (19 September 1996) para 69; Plan de Sanchez Massacre v Guatemala (Reparations) Inter American Court of Human Rights Series C No 116 (19 November 2004) paras 93-103; UN Human Rights Committee, 'Concluding observations on the second periodic report of Bosnia and Herzegovina, adopted by the Committee at its 106th session (15 October-2 November 2012)' (13 November 2012) UN Doc CCPR/C/BIH/CO/2, para 9; Ferida Selimović et al $v$ the Republika Srpska (Decision on Admissibility and the Merits) CH/01/8365 (7 March 2003). ${ }^{105}$ See the Second Protocol to the Hague Convention (n 76). A number of UN Security Council resolutions have emphasised the impermissibility of the trade of cultural objects removed from conflict zones, such as UNSC Res 661 (6 August 1990) UN Doc S/RES/661 on the situation between Iraq and Kuwait; Res 1483 (22 May 2003) UN Doc S/RES/1483 concerning Iraq; Res 2199 (12 February 2015) UN Doc S/RES/2199 concerning Iraq and Syria.

${ }^{106}$ Institute for Human Rights and Development in Africa (on behalf of Esmaila Connateh \& 13 others) $v$ Angola Comm no 292/04 (7-22 May 2008), para 87.
} 


\section{Conclusions}

The right to reparation for victims of armed conflict exists as a matter of law, but what the law says is required is disconnected from what happens in practice. Part of the difficulty is the limited standing for victims to pursue claims to assert their interests, which results in a piecemeal approach largely contingent on States' prerogatives. But there is also a discord between the rigidity of the law and the practice. There is an absence of rules regarding 'second-best' remedies and reparation, particularly how to assess when a State or other wrongdoer is justified even on a temporary basis in affording anything other than 'full' reparation, and what standards should be employed to assess such 'second-best' measures. There are a range of approaches that have been taken by administrative bodies as to how best to address such challenges with a view to realising adequate and effective forms of reparation that correspond to the greatest possible extent to the harm. Language such as 'appropriate', 'effective', 'capable of responding to the harm', suggest that 'second-best' measures must seek to approximate, to the greatest possible extent, 'full' reparation. However, there is nonetheless a tendency for States to start from the standpoint of 'anything goes', with victims struggling to fight for greater rights, which remains an uphill battle. 